\title{
Growth Performance, Yield Component and Genotypic Response of Mungbean (Vigna radiata) Against Soil Borne Diseases
}

\author{
Emerensiana Uge*, Rudi Iswanto, Ratri Tri Hapsari, Trustinah \\ Indonesian Legum And Tuber Crops Research Institute, Indonesia \\ *Email: rensi.uge23@gmail.com
}

Submitted: 1 January 2020. Revised: 11 February 2020. Accepted: 20 March 2020

\begin{abstract}
Soil-borne disease caused by fungus infection is one of the disease that causes the death and crop failure of mungbean. The aim of this study was to identify the performance, yield component and respons of plant to the disease. Performance of 25 genotypes were observed in installations research and assessment of agriculture technology (IPPTP), Jambegede of Indonesian Legumes and Tuber Crops Research Institute (ILETRI) at dry season 2018 using RCBD with three replications. The result showed that each variety has different characteristic. The plant with the highest number of plant height was genotype 15 and 18 , while the total branches of 25 genotypes were generally similar (4).The highest number of grown and harvested plant was genotype 15 . The genotypes with shorter flowering, maturity and harvesting age were $23,20,18,15$ and 10 . The highest average number of filled pods was genotype 11 and empty pods was genotype 13 . There were 8,10 and 2 genotypes with seeds weight of $>7,>6$ and $<6$ respectively. The highest yields were obtained from genotype 19 and 3 by total of yield of 2.0 t/ha and 1,9 ton/ha respectively. Resistance test against soil-borne diseases resulted 5 genotypes that were moderate resistant observed at 2 DAP. This research contributed to gave information about new genotypes of mungbean that potentially produce new superior varieties.
\end{abstract}

Key words: mungbean, yield component, soil-borne diseases

How to Cite: Uge, E., Iswanto, R., Hapsari, R. T., \& Trustinah. (2020). Growth Performance, Yield Component and Genotypic Response of Mungbean (Vignaradiata l.) Against Soil Borne Diseases. Biosaintifika: Journal of Biology \& Biology Education, 12 (1), $57-63$

DOI: http://dx.doi.org/10.15294/biosaintifika.v12i1.23827

\section{INTRODUCTION}

Mungbean is an important commodity in food crops sub-sectors. Mungbean is one of the sources of vegetable protein. The nutritional content in $100 \mathrm{~g}$ of mungbean are protein 4.6-33.0 $\mathrm{g}$ and iron 5.9-7.6 mg (Dahiya et al., 2015). Sutrisno and Yusnawan (2018) showed that varietas Vima 1 contains phenols $(2,123$ $\mathrm{mg} \mathrm{GAE} / \mathrm{g})$ and flavonoids $(0,764 \mathrm{mg} \mathrm{CE} / \mathrm{g})$, that contribute to its antioxidant activity. High nutrient and secondary metabolite content make the products of this commodity are widely used as food, feed and industrial raw material. Increased demand for raw material,affects the demand for mungbean production. Mungbean production in Indonesia often fluctuates

every year. Indonesia national mungbean production data in 2015-2016 are 271.463 and 252.985 tons/ha. This production value is higher compared to 2017 which is 241.334 tons (Kementerian Pertanian, 2018). One effort to increase the productivity of mungbeans is by creating new high yielding varieties. Superior variety is one of technologies designed to facilitate farmers which application is accessible, affordable and environmentally friendly. The benefit of using mungbeans from superior varieties is to in- crease the productivity of mungbeans in several regions (Trustinah et al., 2014).

Mungbeans are early maturing plants, which are drought tolerant and can grow on infertile field, so that it is suitable to be cultivated in several areas in Indonesia especially in dry land on dry climate such as NTT (Yusuf, 2014). Assembling superior varieties can support the development and production of mungbeans in Indonesia. New improved of superior variety should have good plant characteristics including the characteristics of vegetative and generative growth as well as its productivity. Several varieties of mungbeans have been released by the Indonesian Legumes and Tuber Crops Research Institute (ILETRI), including varieties Vima 1, Vima 2, Vima 3 , Vima 4 and Vima 5 which have their respective advantages. Vima 1 known as salinity tolerant variety (Hapsari \& Trustinah, 2018), but the mungbean varieties that resistant against soil-borne disease has not been found before.

As the environment changes and the increase in demand for certain characters occurs, breeding continues to focus on meeting the society demands by producing new varieties. The aim of this study was to evaluate the performance of growth and yield of some mungbean genotypes and their response to soil-borne 
pathogen infections. This study would be able to provide information in the development of new superior varieties of mungbeans. The new superior varieties obtained are expected to overcome the limitations of varieties with highyield potential, early maturity, seed characteristics according to consumer needs, and tolerant of soil infectious diseases.In addition, the resulting genotype is expected to reduce the use of chemical pesticides and production costs.

\section{METHODS}

This research was conducted in endemic soilborne disease land on installations research and assessment of agriculture technology (Instalasi Penelitian dan Pengkajian Teknologi Pertanian/ IPPTP) Jambegede, Malang District, at the first of Dry Season (DS I) in 2018. The design used was Randomized Complete Block Design (RCBD), with treatment using 25 genotypes of mungbean plants (including 5 comparison genotypes, Vima 1, Vima 2, Vima 3, Vima 4 and Vima 5) (Table 1), and three times repetition. Mungbeans were planted in several plots in field of 18.75 acre, each plots measured 6.42 $\mathrm{m}^{2}$, with a spacing of $40 \mathrm{~cm} \times 10 \mathrm{~cm}$. The seeds were planted 2 of each planting holes. Fertilizer was applied at the planting time in an array $(50 \mathrm{~kg}$ of urea, $100 \mathrm{~kg}$ of SP36, and $50 \mathrm{~kg} \mathrm{KCl}$ ), while the maintenances included weed (15 and 25 Days after planting (DAP)) and pest control.

Observation was performed for plant height, number of branches, number of grown and harvested plants, flowering stages and maturity age, number of filled and empty pods, weight of 100 seeds, seeds yield and the diseases incidence. The diseases incidence was calculated using the incidence formula;

$$
\mathrm{DI}=\frac{n}{N}+100 \%
$$

Description :DI= disease incidence; $\mathrm{n}=$ number of symptomatic plants; $\mathrm{N}=$ number of observed plants.

The data were analysed using Analysis of Variance (ANOVA) continued with LSD test. The characterizing of resistance level was performed according to infection intencity by Hardaningsih (2007) i.e: Very resistance $=$ infection intesity 0 ; resistance $=$ infection intesity $>0-10 \%$, Moderate resistance $=$ infection intesity $>10 \%-25 \%$, Moderate susceptible $=$ infection intesity $>25 \%-50 \%$, Susceptible $=$ infection intesity $>50 \%$.

\section{RESULTS AND DISCUSSION}

\section{The Plant Growth, and Number of Grown and Harvested Plants}

Generally, the normal plant growth are shown by the high performace of plant with plant height average of $60.13 \mathrm{~cm}$, by range of $48.4-70.09 \mathrm{~cm}$ (Table 2). The result of ANOVA showed that the yield and yield component were different among tested genotypes. The average value of plant growth (plant height and number of branches), number of grown plants, number of mature plants, flowering age, and plant's maturity (age) are showed in Table 2 .

Table 1. The name of mungbean genotypes

\begin{tabular}{ll}
\hline No & Name Genotype \\
\hline 1 & MMC 763d-Mn-10-5 \\
2 & MMC 763d-Mn-10-12 \\
3 & MMC 767c-Mn-26-9 \\
4 & MMC 783c-Mn-28-11 \\
5 & MMC 784c-Mn-29-8 \\
6 & MMC 784c-Mn-29-10 \\
7 & MMC 832c-Mn-114-7 \\
8 & MMC 844c-Mn-115-5 \\
9 & MMC 844c-Mn-115-6 \\
10 & MMC 844c-Mn-115-15 \\
11 & MMC 812c-Mn-117-3 \\
12 & MMC 851c-Mn-121-2 \\
13 & MMC 828c-Mn-131-4 \\
14 & MMC 837c-Mn-133-2 \\
15 & MMC 837c-Mn-133-6 \\
16 & MMC 838c-Mn-134-2 \\
17 & MMC 838c-Mn-95-0 \\
18 & MMC 846c-Mn-137-5 \\
19 & MMC 859c-Mn-48-2 \\
20 & MMC 859c-Mn-48-6 \\
21 & Vima 4 \\
22 & Vima 5 \\
23 & Vima 1 \\
24 & Vima 2 \\
25 & Vima 3 \\
\hline
\end{tabular}

Genotype number 15 has the highest plant performance $(70.09 \mathrm{~cm})$, followed by genotype number 18 with a plant height of $69.23 \mathrm{~cm}$ (Table 2).Tall plants have more chance to get more sunlight than short plants which can accelerate the process photosynthesis, metabolism and plant growth. Data of the number of branches showed that there were 3 genotypes with lower mean value (3), while the other 22 genotypes were higher (4). According Toker (2004), in breeding of legumes, it is important to observe the plant biological characteristic such as plant height, number of branches, number of pods and others. Biological characteristics have a positive and high contribution to crop yields, that make the biological characters can be used for selection in mungbean breeding programs (Canci \& Toker, 2014).

Observation of the number of grown and harvested plants showed that the mean value respectively were 
219 and 211. The highest number of grown and harvested plants was obtained from genotype 15, while the lowest number was from 13 (Table 2). These results indicate that the number of early grown plants influences the number of plants harvested. The ability of seeds to germinate and grow is one of the good plant characters, which is expected to have a high number of plant populations that affect the number of harvested plants.

Table 2. Average value of plant height, number of branches, number of grown plants and number of harvested plant of 25 mungbean genotypes in Jambegede at the first dry season (DS 1) 2018

\begin{tabular}{|c|c|c|c|c|c|c|}
\hline \multirow[b]{2}{*}{ G } & \multicolumn{6}{|c|}{ Mean of Yield and Growth Component } \\
\hline & $\begin{array}{l}\text { Plant } \\
\text { height } \\
(\mathrm{cm})\end{array}$ & $\begin{array}{l}\text { Number } \\
\text { of } \\
\text { branches }\end{array}$ & $\begin{array}{l}\text { Number } \\
\text { of grown } \\
\text { plants }\end{array}$ & $\begin{array}{l}\text { Number of } \\
\text { harvested } \\
\text { plants }\end{array}$ & FA & MA \\
\hline 1 & 53.60 & 3 & 246 & 239 & 38 & 62 \\
\hline 2 & 59.92 & 4 & 209 & 203 & 37 & 63 \\
\hline 3 & 64.01 & 4 & 214 & 207 & 37 & 63 \\
\hline 4 & 67.03 & 4 & 223 & 217 & 39 & 65 \\
\hline 5 & 53.38 & 4 & 231 & 224 & 38 & 63 \\
\hline 6 & 54.57 & 4 & 222 & 215 & 39 & 64 \\
\hline 7 & 59.39 & 4 & 207 & 200 & 40 & 65 \\
\hline 8 & 59.89 & 4 & 222 & 213 & 41 & 66 \\
\hline 9 & 65.65 & 4 & 225 & 215 & 39 & 64 \\
\hline 10 & 65.36 & 3 & 217 & 209 & 39 & 64 \\
\hline 11 & 60.27 & 4 & 225 & 219 & 37 & 62 \\
\hline 12 & 61.27 & 4 & 213 & 206 & 40 & 65 \\
\hline 13 & 65.53 & 4 & 187 & 178 & 41 & 65 \\
\hline 14 & 66.89 & 4 & 223 & 216 & 40 & 65 \\
\hline 15 & 70.09 & 4 & 253 & 246 & 37 & 63 \\
\hline 16 & 54.76 & 4 & 237 & 228 & 39 & 63 \\
\hline 17 & 62.05 & 4 & 228 & 220 & 40 & 64 \\
\hline 18 & 69.23 & 4 & 232 & 217 & 39 & 64 \\
\hline 19 & 58.78 & 4 & 219 & 207 & 39 & 63 \\
\hline 20 & 56.53 & 4 & 211 & 204 & 38 & 63 \\
\hline 21 & 58.50 & 4 & 206 & 200 & 39 & 65 \\
\hline 22 & 53.15 & 3 & 212 & 206 & 44 & 64 \\
\hline 23 & 48.41 & 4 & 197 & 190 & 37 & 62 \\
\hline 24 & 51.97 & 4 & 201 & 191 & 38 & 63 \\
\hline 25 & 63.09 & 4 & 205 & 197 & 41 & 64 \\
\hline Average & 60.13 & 3.9 & 219 & 211 & 39 & 64 \\
\hline LSD & 6.78 & 0.80 & 36.11 & 35.69 & 1.68 & 1.46 \\
\hline
\end{tabular}

Note: FA: Flowering Age, MA: Maturity Age

Flowering age is the age of plants entering the generative phase. The shorter flowering age means the shorter maturity and harvesting age of a plant. Table 3 shows that 2 genotypes have a flowering age at 37 DAP equivalent to Vima 1 were genotypes 2 and 3; and 38 DAP equivalent to Vima 2 i.e 1, 5 and 20. Early maturity age showed on 62 DAP at genotypes 1 and 11 which was equivalent to Vima 1 and 63 DAP equivalent to Vima 2 (genotypes 2, 3, $5,15,16,19$, and 20). In the observations of harvesting age, harvesting age in all genotypes generally ranged between 65 and $72 \mathrm{DAP}$, this longer than the comparative varieties of Vima, which ranged between 64- 67 .

The difference between the results in this study and the characters in the varieties description can be influenced by various environmental factors that occur during crop cultivation. Observation result of Vima 1 variety in several different regions showed that the maturity age of Vima 1 at Demak (Prasetiaswati \& Radjit, 2011) and Gowa (Radjit et al., 2012) planting site was 58 DAP, while at Muneng Banyuwangi it was 55 DAP (Pratiwi et al., 2013), and 60 DAP (Seran et al., 2012). Basically, the difference 
of flowering and maturity age are caused by genetic influence of each genotype. Asadi et al, (2017) stated that the varied background of plant parents influences their morphological and agronomic characters, so that they appear to have specific characteristics. In some cases are concluded that there are location and micro environment influence to the plant age.

\section{The Number of Filled Pods, Empty Pods and Weight of 100 Seeds}

Highest average number of filled pods was obtained from genotype 11 (14 pods), while the lowest was from genotype 12 (10 pods). The range of filled pods in the all varieties were 10-14 pods. The lowest average number of empty pods was in genotype $6(0)$, while the highest was in genotype 13 (2). The other 18 genotypes had the same average number of empty pods (1) (Table 3). The number of filled pods is one yield component that has a positive correlation to the yield. The number of pods filled in this study was similar to Silva \& Murdolelono's research (2014), the Vima, sriti and kenari varieties had filled pods average were 10 , whereas with the addition of manure could increase the filled pods (Raihan et al., 2011). Other research also stated that there are influences from environmental factors such as drought stress that affect the number of pods in mungbeans (Mirzaei et al., 2014).

The weight of 100 seeds indicates the size of the seed. Based on Table 3, there are $7(3,4,5,10,11$, 13, 18 and 20) of mungbeans with a weight of 100 seeds value of $>7$ grams, equivalent to the comparative varieties of Vima 2, Vima 4 and Vima 5. There are 12 genotypes with seed weight values of $>6$ grams that is equivalent to the comparison varieties of Vima 1 and Vima 3, while the other 2 genotypes (8 and 14) have seed weights of $<6$ grams. Mungbean plants with the character of big seeds are in great demand by the bread industry and food products, while the character of small seeds is usually in demand of the sprouts industry (Trustinah et al, 2014). Information related to seed weight, is important for consumers to help them choosing varieties that suit their needs.

\section{Seeds Yield of Mungbean}

Data from this study indicate that genotype has a significant effect on seed yield (Figure 1). The genotype with highest seed yield was genotype 19 which was 2 tons / ha, followed by genotype 3 which was 1.9 tons / ha, while the genotype with the lowest yield was genotype 22 with seed yields 1 ton / ha. In the results of this study the yields of Vima varieties were generally lower than the optimum potential yields, ranging from 1.44-1.82 tons/ha, and lower than the average yield of 20 strains of seeds, ranging from
1.50-2 tons/ha. There was differences of seed yields in this research and those in the varieties description i.e (Table 4).

Table 3. Average of genotype effect towards filled pods number, empty pods numbers, 100 seeds weight and seeds yield of mungbean plants.

\begin{tabular}{|c|c|c|c|}
\hline \multirow{2}{*}{$\mathbf{G}$} & \multicolumn{3}{|c|}{ Mean of field and growth component } \\
\hline & FPN & EPN & 100 Seeds weight (gram) \\
\hline 1 & 11 & 1 & 6.94 \\
\hline 2 & 12 & 1 & 6.78 \\
\hline 3 & 12 & 1 & 7.12 \\
\hline 4 & 10 & 1 & 7.34 \\
\hline 5 & 11 & 1 & 7.24 \\
\hline 6 & 11 & $\mathbf{0}$ & 6.86 \\
\hline 7 & 12 & 1 & 6.80 \\
\hline 8 & 12 & 1 & 5.99 \\
\hline 9 & 11 & 1 & 6.54 \\
\hline 10 & 12 & 1 & 7.46 \\
\hline 11 & 14 & 1 & 7.27 \\
\hline 12 & 10 & 1 & 6.70 \\
\hline 13 & 13 & 2 & 7.02 \\
\hline 14 & 12 & 1 & 5.94 \\
\hline 15 & 11 & 1 & 6.56 \\
\hline 16 & 12 & 1 & 6.64 \\
\hline 17 & 11 & 1 & 6.97 \\
\hline 18 & 13 & 1 & 7.27 \\
\hline 19 & 11 & 1 & 6.61 \\
\hline 20 & 12 & 1 & 7.38 \\
\hline 21 & 12 & 1 & 7.29 \\
\hline 22 & 11 & 1 & 7.17 \\
\hline 23 & 13 & 1 & 6.71 \\
\hline 24 & 11 & 1 & 7.04 \\
\hline 25 & 13 & 1 & 6.57 \\
\hline Average & 11.72 & 1 & 6.88 \\
\hline$L S D$ & 2.99 & 1.11 & 0.41 \\
\hline
\end{tabular}

Note: G: Genotype,FPN: Filled Pods Number; EPN: Empty Pods Number

Table 4. The comparison of seed yield on research and potential yield in variety description

\begin{tabular}{ccc}
\hline Variety & $\begin{array}{c}\text { Seed yield on } \\
\text { this reserach } \\
\text { (Tons/ha) }\end{array}$ & $\begin{array}{c}\text { Potential yield in varie- } \\
\text { ties description (Tons/ha) }\end{array}$ \\
\hline Vima 1 & 1.61 & 1.76 (Balitkabi, 2008) \\
Vima 2 & 1.68 & 2.44 (Balitkabi, 2014) \\
Vima 3 & 1.70 & 2.11 (Balitkabi, 2014) \\
Vima 4 & 1.82 & 2.32 (Balitkabi, 2018) \\
Vima 5 & 1.44 & 2.34 (Balitkabi, 2018) \\
\hline
\end{tabular}

Saleh \& Agustina's study (2017) in the swamp showed that the yield of Vima seeds was 1.36 tons/ha. Yield production are influenced by genetic characteristics and environmental factors at the time of cultivation, so that, some new genotypes in this research are 
recommended to be used in the selection of superior varieties of mungbeans.

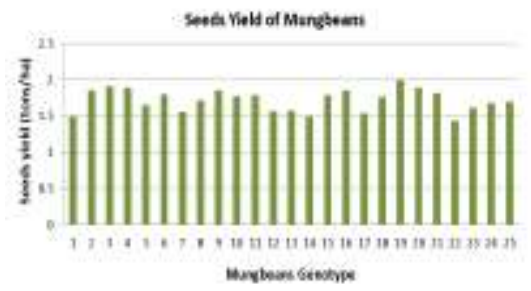

Figure 1. The seeds yield of 25 mungbeans genotypes on planting at the first dry season (DS 1) in IPPTP Jambegede

\section{Response of Mungbeans Genotype Againts Soil- borne Pathogen}

Mungbean production is influenced by environmental factors both biotic and abiotic. One of the biotic factors that affect the plant growth is infection of soil-borne pathogens. Some researchers reported that the Jambegede IPPTP area is an endemic area for soil-borne diseases. Infection of soil contagious fungi is often observed in various plants of beans and tubers (Balitkabi as cited in Sumartini, 2011). Infection in mungbean plants in Jambegede IPPTP was reported to be caused by Rhizoctonia solani (Inayati et al., 2016). Tantawizal \& Rahayu (2017), also examined the control of Sclerotium rolfsii in the same IPPTP on peanut commodities and resulted that soil-borne microbial infections, tend to increase during plant development from vegetative to generative phases.

The observations results of infected plants at 2 weeks after planting (WAP) showed that mungbean plants infected by soil-borne pathogens were generally symptomatic withered and died. Initial symptoms of wilt in plants showed similar with symptom of water lacking. Plants that have advanced infections and died will be easily uprooted because of root rot conditions due to pathogenic infections. Infection in seedlings causes the damping off problem (Figure 2). In some cases fungus mycelium are found around the planting hole and plant roots or stems. In other cases, plant death due to bacterial infection generally shows no sign. The typical sign of S.rolfsii infection are the presence of sclerosia (small white to brown granules) (Gorbet et al., 2004).

The initial phase of plant growth is a vulnerable phase, but infection is often found in the generative phase of susceptible varieties. The calculation of disease incidence was performed by counting the number of infected plants per total number of plants observed. The observations result of disease incidence in the field can be used to determine the tolerance level of plants. The tolerance level of 25 mungbean genotypes against soil-borne diseases is determined based on the criteria of resistance (Hardaningsih, 2007). Anova test of disease incidence value in 2 week after planting (WAP) showed that there were significant differences between genotypes, and based on the determination of the value the genotypes were categorized asmoderately resistant and moderate susceptible criteria. The disease incidence value in genotypes that are considered moderately resistant is $20 \%$, while the criteria for susceptibility are ranging from 26.67 to $40 \%$ (Table 5).

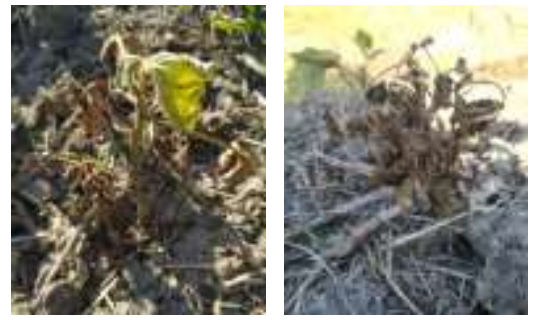

Figure 2. MortalitySymptom of mungbean plant suspected as soil-borne pathogen infection; (a) the withered plant and (b) dead plant.

Table 5. Average number of genotype effect to flowering ages, mature age and harvesting age

\begin{tabular}{lll}
\hline G & DI & RC \\
\hline MMC 763d-Mn-10-5 & $40 \mathrm{ab}$ & MS \\
MMC 763d-Mn-10-12 & $27 \mathrm{ab}$ & MS \\
MMC 767c-Mn-26-9 & $27 \mathrm{ab}$ & MS \\
MMC 783c-Mn-28-11 & $33 \mathrm{ab}$ & MS \\
MMC 784c-Mn-29-8 & $33 \mathrm{ab}$ & MS \\
MMC 784c-Mn-29-10 & $27 \mathrm{ab}$ & MS \\
MMC 832c-Mn-114-7 & $27 \mathrm{ab}$ & MS \\
MMC 844c-Mn-115-5 & $27 \mathrm{ab}$ & MS \\
MMC 844c-Mn-115-6 & $27 \mathrm{ab}$ & MS \\
MMC 844c-Mn-115-15 & $33 \mathrm{ab}$ & MS \\
MMC 812c-Mn-117-3 & $33 \mathrm{ab}$ & MS \\
MMC 851c-Mn-121-2 & $20 \mathrm{~b}$ & MR \\
MMC 828c-Mn-131-4 & $20 \mathrm{~b}$ & MR \\
MMC 837c-Mn-133-2 & $27 \mathrm{ab}$ & MS \\
MMC 837c-Mn-133-6 & $20 \mathrm{~b}$ & MR \\
MMC 838c-Mn-134-2 & $27 \mathrm{ab}$ & MS \\
MMC 838c-Mn-95-0 & $27 \mathrm{ab}$ & MS \\
MMC 846c-Mn-137-5 & $20 \mathrm{~b}$ & MR \\
MMC 859c-Mn-48-2 & $27 \mathrm{ab}$ & MS \\
MMC 859c-Mn-48-6 & $33 \mathrm{ab}$ & MS \\
Vima 4 & $33 \mathrm{ab}$ & MS \\
Vima 5 & $20 \mathrm{~b}$ & MR \\
Vima 1 & $33 \mathrm{ab}$ & MS \\
Vima 2 & $33 \mathrm{ab}$ & MS \\
Vima 3 & $27 \mathrm{ab}$ & MS \\
\hline Average & \\
\hline LSD & & \\
\hline
\end{tabular}

Note: Numbers in the treatment row followed by the same letter are not significantly different according to LSD test with $\alpha=5 \%$. G: Genotype,DI: Disease Incidence, RC: Resistance Character, $\mathrm{MR}=$ Moderate resistance, $\mathrm{MS}=$ Moderate susceptible 
Diseases incidence data at 2 WAP showed that the genotypes considered moderate resistance genotypes $(12,13,15$, and 18) have the same chriteria with comparison variety 22 (Vima 5) (Table 5). Variety Vima 5 is known as mungbean variety with moderate resistance against thrips infestation and soil-borne disease (Balitkabi, 2017). The results of this study can provide information related to the diversity of growth, crop yields and the resistance criteria of mungbean potential varieties to soil-borne pathogens. This research can gave information about new genotypes of mungbean that potentially produce new superior varieties and be a reference for breeders and users to choose the right genotype according to their needs.

\section{CONCLUSION}

Data growth component showed that the highest number of grown plants and harvested plants was obtained from genotype 15 . The highest plant height and number of branches was obtained from genotype 15 and 18, while the total branches of 25 genotypes were generally similar (4).There were five genotypes with shorter flowering, maturity and harvesting age.The data of field component showed that, the highest average number of filled pods was obtained from genotype 11 and empty pods was from genotype 13. There were genotypes 8,10 and 2 which have seeds weight $>7,>6$ and $<6$ grams respectively. The highest yield on this research were 2.0 and 1.9 ton/ha, and there were also found 5 genotypes that resistant to soil-borne disease observed at 2 DAP.

\section{REFERENCES}

Asadi, S., Dewi, N.,\& Bora, C.S. (2017). Respons Aksesi Plasma Nutfah Kacang Hijau terhadap Cekaman Kekeringan. Buletin Plasma Nutfah, 23(2), 101-108.

Balitkabi, (2008, November 29). Varietas Unggul Kacang Hijau. Retrieved from http://balitkabi.litbang.pertanian.go.id/varietasunggul/vu-kacang-hijau/vima-1/.

Balitkabi, (2014, May 7). Vima 2 dan Vima 3 Varietas Kacang Hijau Terbaru. Retrivied from http://balitkabi.litbang.pertanian.go.id/infotek/vim a-2-dan-vima-3-varietas-kacang-hijau-terbaru/.

Balitkabi, (2017, April 27).Vima 4 dan Vima 5: VUB, kacang hijau umur genjah, hasil tinggi, toleran hama thrips dan penyakit tular tanah. Retrieved from

http://balitkabi.litbang.pertanian.go.id/infotek/vim a-4-dan-vima-5-vub-kacang-.hijau-umur-genjahhasil-tinggi-toleran-hama-thrips-dan-penyakittular-tanah/.
Balitkabi, (2018, February 27). Deskripsi Varietas Terbaru. Retrivied from http://balitkabi.litbang. pertanian.go.id/informasi/deskripsi-varietasterbaru/.

Canci, H., \& Toker, C. (2014). Yield components in Mungbean (Vigna radiata (L) Wilczek. Turkish Journal of Field Crops, 19(2), 258-261.

Dahiya, P.K., Linnemann, A.R., Van Boekel M.A.J.S., Khetarpaul, N., Grewal R.B., \& Nout M.J.R. (2015). Mungbean: Technological and $\mathrm{Nu}-$ tritional Potential. Critical Reviews in Food Science and Nutrition, 55:670-688. DOI: 10.1080/ 10408398.2012.671202

Gorbet, D.W., Kucharek, T.A., Shokes, F.M., \& Brenneman, T.B. (2004). Field evaluations of peanut germplasm for resistance to stem rot caused by Sclerotium rolfsii. Peanut Science. 31, 91-95.

Hapsari., \& Trustinah. (2018). Salinity tolerance of Mungbean Genotypes at seedling stage. Biosaintifika 10 (2), 408-415. DOI: http://dx.do i.org/10.15294/biosaintifika.v10i2.13999

Hardaningsih, S. (2007, August). Antagonism of Trichoderma spp. to Mungbean Phytophthora sp in Laboratory. Paper presented at The Third Asian Conference on Plant Pathology, Yogyakarta, Indonesia.

Inayati, A., Dwi, S.S., Yusnawan, E., \& Hapsari, R.T. (2016, Mei 25). Evaluasi Ketahanan Plasma Nutfah Kacang Hijau terhadap Penyakit Busuk Akar Rhizoctonia. Paper presented at Conference on research result of Legumes and Tuber Crops, Malang, Indonesia.

Kementerian pertanian. (2018, juli 25-27). Produksi Kacang Hijau Menurut Provinsi, 2014 - 2018. http://www.pertanian.go.id/home/?show=page \&ac $\mathrm{t}=$ view\&id=61. Diakses 14-06-2019.

Mirzaei, A., Naseri, R., Vafa, P., \& Moradi, M. (2014). Effects of drought stress on qualitative and quantitative traits of mungbean. International Journal of Agricultural and Biosystems Engineering, 8 (2), 144-148.

Prasetiaswati, N., \& Radjit, B.S. (2011). Kajian dampak penerapan varietas kacang hijau Vima 1 dan komponen teknologi pendukungnya di lahan sawah. Buana Sains, 11(1),17-24.

Pratiwi, H., Rahmiana A.A., \& Taufiq, A. (2013). Perbandingan fenologi beberapa varietas unggul kacang hijau pada pertanaman awal musim hujan. p. 477-482. Dalam: Rahmiana AA et al. (Eds.). paper presented at Seminar Hasil Penelitian Tanaman Aneka Kacang dan Umbi Tahun 2012. Peningkatan daya saing dan implementasi pengembangan komoditas kacang dan umbi mendukung pencapaian empat sukses pembangunan pertanian. Puslitbangtan. Bogor. 
Radjit, B.S., \& Prasetiaswati, N. (2012). Prospek kacang hijau pada musim kemarau di Jawa Tengah. Buletin Palawija, 24, 57-68.

Raihan, S., Saleh, M., \& William, E. (2011). Penampilan tiga varietas kacang hijau di lahan rawa pasang surut sulfat masam Tipe B. hlm 520524. in M.M. Adie, Sholihin, A.A. Rahmianna, I Ketut Tastra, Fachrur Rozi, Hermanto, Apri Sulistyo dan Sumartini (eds). Inovasi Teknologi untuk Penegmbangan Kedelai Menuju Swasembada. Puslitbangtan. Badan Litbang Pertanian. 2011.

Saleh, M., \& Agustina, R. (2017). Keragaan Lima Varietas Kacang Hijau (Vigna radiata L.) di Lahan Rawa Lebak Dangkal. Prosiding Seminar Hasil Penelitian Tanaman Aneka Kacang dan Umbi 2017: 482-487

Silva, H.D., \& Murdolelono, B. (2014, Mei 22). Keragaan Varietas unggul baru kacang hijau. hlm 478-482. Dalam Nasir Saleh et al (eds). Paper presented at national conference on research result of Legumes and Tuber Crops 2013, Malang, Indonesia

Sumartini. (2011). Penyakit Tular Tanah (Sclerotium rolfsii dan Rhizoctonia solani) pada tanaman kacang-kacangan dan umbi-umbian serta cara pengendaliannya. Jurnal litbang pertanian, 31(1), 27-34.

Toker, C. (2004). Evaluation of selection criteria using phenotypic and factor analysis in chickpea.
Acta Agric. Scan. Section B, Soil and Plant Science, 54, 45-48.

Seran, Y.L., Kote, M., \& Benu, F.L. (2012). Pengembangan kacang hijau varietas unggul Vima 1 di kabupaten Belu, NTT.p.546-553. in: Widjono A et al. (Eds.). paper presented at Seminar Hasil Penelitian Tanaman Aneka Kacang dan Umbi Mendukung Empat Sukses Kementerian Pertanian. Inovasi teknologi dan kajian ekonomi komoditas aneka kacang dan umbi mendukung empat sukses Kementerian Pertanian. Puslitbangtan. Bogor.

Sutrisno., \& Yusnawan, E. (2018). Effect of manure and inorganic fertilizers, on Vegetatif, Generative Characteristics, nutrient and secondary metabolite contents of Mungbean. Biosaintifika, 10(1), 56-65. DOI: 10.15294/biosaintifika.v10i1.12716

Tantawizal., \& Rahayu, M. (2017). Insidensi Penyakit Layu Sclerotium rolfsii pada beberapa varietas kacang tanah dan aplikasi agens pengendali hayati. Primordia, 13(1), 24-28.

Trustinah., Radjit, B.S., Prasetiaswati, N., \& Harnowo, D. (2014). Adopsi varietas unggul kacang hijau di sentra produksi. Iptek tanaman pangan, 9, 24-38.

Yusuf. (2014, Juni 5). Pemanfaatan kacang hijau sebagai pangan fungsional mendukung diversifikasi pangan di Nusa Tenggara Timur. Paper presented at Conference on research result of Legumes and Tuber Crops 2014, Malang, Indonesia 